\title{
WORD OF MOUTH UNTUK MEMPERKUAT BRAND POSITIONING "THE HOUSE OF RAMINTEN SEBAGAI ANGKRINGAN “TRADISIONAL MODERN” DI YOGYAKARTA
}

\author{
Fitria Ayuningtyas ${ }^{1}$, Uljanatunnisa ${ }^{2}$ \\ Fakultas Ilmu Sosial dan Ilmu Politik \\ Universitas Pembangunan Nasional Veteran Jakarta \\ e-mail : fitria.irwanto@upnvj.ac.id ${ }^{1}$, uljanatunnisa@upnvj.ac.id ${ }^{2}$
}

\begin{abstract}
Many cities in Indonesia offering all sorts of things that can attract local tourist's attraction to come to that city such as the food that serve as culinary tourism or natural tours that offer an exotic's view and so forth. Yogyakarta could not separate from culinary tourism, it means every tourist who came to Yogyakarta would like to try specialty culinary in this area. One of the famous angkringan culinary in Yogyakarta is The House of Raminten. This place is very familiar with eccentric angkringan in Yogyakarta. Beside that The House of Raminten is the only one who has traditional modern's concept in Yogyakarta. Recognizing the importance of brand in customer's mind, Management of The House of Raminten try to develop brand positioning namely angkringan traditional modern's concept as strategy to make a differentiation with their competitors. For both of local tourists and or foreign tourists, The House of Raminten known thru information from individual to other individual or individual to group to speed up an information spread widely, called as word of mouth. The purpose of this research to know the role of word of mouth on strengthening brand positioning in The House of Raminten. This research used theory: word of mouth's concept in marketing communication, target segmentationa and brand positioning. The method of this research used qualitative method. The results of this research is the role of word of mouth on strengthening brand positioning very high and strongly although other promotion can strengthen brand positioning indirectly.
\end{abstract}

Keywords: word of mouth, strengthening, brand, positioning

\begin{abstract}
Abstrak
Beberap kota di Indonesia menawarkan segala macam hal yang bisa menarik daya tarik wisata lokal untuk sampai ke kota yang akan dituju, seperti makanan yang berfungsi sebagai wisata kuliner atau wisata alam yang menawarkan pemandangan eksotis dan sebagainya. Yogyakarta tidak bisa lepas dari wisata kuliner, artinya setiap wisatawan yang datang ke Yogyakarta ingin mencoba kuliner khas di daerah tersebut. Salah satu kuliner angkringan yang terkenal di Yogyakarta adalah The House of Raminten. Tempat ini sangat akrab dengan angkringan eksentrik di Yogyakarta. Selain itu The House of Raminten adalah satu-satunya yang memiliki konsep modern tradisional di Yogyakarta. Menyadari pentingnya brand dalam benak konsumen, Manajemen Rumah Raminten mencoba mengembangkan brand positioning yaitu konsep tradisional tradisional angkringan sebagai strategi untuk melakukan diferensiasi dengan kompetitornya. Bagi wisatawan lokal maupun turis mancanegara, The House of Raminten dikenal melalui informasi dari individu ke individu lain atau individu ke kelompok untuk mempercepat penyebaran informasi secara luas, disebut dari mulut ke mulut. Tujuan dari
\end{abstract}


penelitian ini untuk mengetahui peran word of mouth dalam memperkuat brand positioning di Rumah Raminten. Penelitian ini menggunakan teori: konsep word of mouth dalam komunikasi pemasaran, segmentasi target dan brand positioning. Metode penelitian ini menggunakan metode kualitatif. Hasil penelitian ini adalah peran word of mouth untuk memperkuat brand positioning yang sangat tinggi dan sangat kuat walaupun promosi lainnya dapat memperkuat brand positioning secara tidak langsung.

\section{Kata kunci: kata dari mulut ke mulut, penguatan, brand, positioning}

\section{LATAR BELAKANG}

Saat ini berbagai kota di Indonesia menawarkan beragam hal yang menarik kepada wisatawan lokal agar datang ke kota tersebut. Hal-hal yang ditawarkan seperti kekhasan suatu makanannya yang dijadikan sebagai wisata kuliner atau wisata alamnya yang menawarkan pemandangan yang eksotik dan lain sebagainya.

Kota Yogyakarta merupakan salah satu destinasi utama bagi wisatawan lokal hingga mancanegara, terlebih saat musim liburan tiba. Tercatat pada Desember 2016 silam, jumlah pengunjung yang datang ke Kota Yogyakarta mengalami peningkatan sebesar $15 \%$

(http://jogja.tribunnews.com/2016/12/14/le ngth-of-stay-rendah-targetkan-spendingtinggi-dari-wisatawan?page $=1$ ).

Keindahan alam, baik gunung maupun lautan, serta keramahan masyarakatnya menjadi daya tarik pengunjung untuk datang kembali ke tempat ini. Selain itu, ragam kuliner yang ditawarkan dengan harga ekonomis juga menjadi daya tarik lainnya.
Yogyakarta memang tidak dapat dipisahkan dari wisata kuliner, setiap wisatawan yang datang, menurut Kadis Pariwisata Yogyakarta Aris Riyanta, memiliki salah satu tujuan untuk merasakan kuliner daerah ini (http://jogja.tribunnews.com/2016/12/14/le ngth-of-stay-rendah-targetkan-spendingtinggi-dari-wisatawan?page $=2$ ). $\quad$ Tidak heran jika akhirnya bisnis kuliner tumbuh pesat, mulai dari kuliner pinggir jalan (angkringan) hingga restaurant.

Angkringan merupakan salah satu ciri khas Kota Yogyakarta. Di tiap sudut kota, sangat mudah menemukan gerobak dorong dengan penerang lampu petromak di pinggir jalan yang menjajakan makanan dan minuman. Lazimnya, angkringan berwujud seperti penjelasan sebelumnya. Namun terdapat satu angkringan di Kota Yogyakarta yang dikenal dengan "The House of Raminten". Tempat ini familier dengan sebutan angkringan nyentriknya Yogyakarta dengan ciri khas tradisional 
modern yang membedakan angkringan ini dengan angkirngan lainnya.

The House of Raminten mengunakan konsep tradisional modern. Di angkringan ini, pengunjung akan disuguhkan dengan nuansa Jawa mulai dari pelayannya yang menggunakan kemben, rompi, serta jarik bercorak batik Jawa hingga interior dan aksesori Jawa seperti bangunan yang didesain dengan arsitektur tradisional dan unik dihiasi kereta, dokar, suatu restoran atau tempat makan tersebut akan sangat signifikan dan citra yang baik tersebut akan selalu dipercaya oleh masyarakat pada akhirnya.

Maka pada penelitian kali ini, peneliti tertarik untuk melihat dari sudut pandang pemasar didasarkan pada kesuksesan manajemen The House of Raminten dalam memosisikan diri mereka sebagai angkringan yang bernuansa tradisional modern di tengah banyaknya wisata kuliner yang memilih lebih mengembangkan konsep modern. Selain itu, konsep tradisional modern, menurut peneliti, merupakan salah satu kondisi untuk mempertahankan nilai-nilai budaya yang semakin tergerus oleh globalisasi dalam rangka menumbuhkan dan mempraktikkan konsep Bela Negara yang sesungguhnya. Dengan mempertahankan konsep tersebut, secara tidak langsung, pemilik angkringan berusaha untuk menunjukan nilai-nilai budaya Jawa yang ditampilkan melalui interior serta atmosfer angkringan.

Telah banyak penelitian yang dilakukan di angkringan The House of Raminten mengingat bahwa angkringan ini telah sukses menjadi salah satu wisata kuliner terbaik di Yogyakarta dan menjadi suatu icon dari Yogyakarta yang tidak pernah lekang dimakan waktu. Beberapa penelitian tersebut membahas citra The House of Raminten terhadap keputusan pembelian. Selain itu juga penelitian terhadap pengaruh atmosfer restoran pada brand image dan minat beli ulang konsumen The House of Raminten Yogyakarta. Namun dari beberapa penelitian yang dilakukan terhadap The House of Raminten, tidak terdapat penelitian terkait segmentasi pasar dan brand positioning yang telah dilakukan oleh manajemen, sehingga penting untuk mengetahui gambaran terkait segmentasi pasar dan brand positioning yang telah dilakukan pihak manajemen mengingat kesuksesan angkringan tersebut. Maka berdasarkan gambaran singkat di atas, topik penelitian yang dipilih untuk melakukan penelitian dengan judul Word of Mouth untuk Memperkuat Brand Positioning The 
House of Raminten sebagai angkringan “Tradisional Modern” di Yogyakarta.

\section{Rumusan Masalah}

Berdasarkan pemaparan di atas, maka rumusan masalah dalam penelitian ini adalah, "Bagaimanakah word of mouth untuk memperkuat brand positioning The House of Raminten sebagai angkringan tradisional modern di Yogyakarta?"

\section{Tujuan Penelitian}

Adapun tujuan dalam penelitian ini adalah untuk mengetahui word of mouth untuk memperkuat brand positioning The House of Raminten sebagai angkringan tradisional modern di Yogyakarta.

\section{TINJAUAN PUSTAKA}

\section{Konsep Word of Mouth dalam Komunikasi Pemasaran}

Kotler dan Keller

mengungkapkan komunikasi pemasaran merupakan perwakilan suara dimana perusahaan dapat membangun dialog dengan pelanggan dan pemangku kepentingan lainnya, tentang penawaran mereka produk atau layanan serta masalah perusahaan lain. Saat ini komunikasi pemasaran semakin diminati para pelaku industri dikarenakan kegiatan komunikasi pemasaran sangat bervariasi mulai dari isi pesan tentang sebuah brand ataupun perusahaan.

Karena sifatnya yang menekankan komunikasi dua arah, maka penyampaian pesan yang semula dilakukan oleh pemasar terhadap konsumen telah berubah menjadi komunikasi yang dilakukan oleh konsumen terhadap konsumen lainnya. Situasi ini sebenarnya memberikan dampak positif dan negatif bagi seorang pemasar. Di satu sisi pemasar tidak dapat mengontrol pesan yang disampaikan oleh konsumen, tetapi di sisi lainnya perusahaan dapat menekan biaya promosi terhadap sebuah brand. Word of mouth (WOM) merupakan salah satu strategi pemasaran yang ampuh, selain biaya pengeluaran rendah karena menggunakan konsumen sebagai promotor WOM lebih dapat dipercaya dibandingkan iklan komersial yang ditayangkan melalui media cetak maupun media online karena word of mouth dianggap hasil dari pengalaman seorang konsumen sehingga menimbulkan persepsi terhadap sebuah brand dan terpenting word of mouth dianggap bebas dari berbagai kepentingan. Secara tak sadar sebenarnya saat ini word of mouth telah banyak membantu para pemasar dalam memasarkan sebuah produk hingga pada tahap memperkenalkan brand sebuah perusahaan. 
Shi dkk (2016) mengungkapkan bahwa word of mouth atau yang disebut dengan oral komunikasi merupakan salah satu faktor yang berperan serta dapat mempengaruhi ekspektasi konsumen pada tingkatan tertentu, harapan pada tingkat di mana pelanggan ingin mendapatkan produk atau pelayanan yang baik. Oleh sebab itu, WOM merupakan komunikasi informal, atau dapat disebut dengan komunikasi yang terjadi antara konsumen dengan konsumen mengenai sebuah produk baik dari segi produk ataupun layanan jasa, antara konsumen mengenai pemasok dan atau karakteristik layanan produk. Yu \& Tang dalam Virvilaite dkk (2015) mengungkapkan karakteristik dari word of mouth yaitu (1) menarik dan kegunaan, (2) dapat mempengaruhi konsumen.

Selain itu untuk mengefektifkan word of mouth, Sernoviz (2012: 19) mengungkapakn lima hal yang harus diperhatikan agar word of mouth dapat menguntungkan bagi pemasar, yaitu:

1. Talkers adalah sebagai seorang komunikator yang memiliki antusias serta terkoneksi dengan individu lainnya (teman, keluarga, rekan kerja dll).

2. Topics merupakan pesan yang disampaikan oleh talkers (komunikator) terkait sebuah brand.
3. Tools adalah perlengakapan atau saluran komunikasi yang digunakan oleh talkers dalam menyampaikan topics. Tools dalam penelitian ini adalah WOM.

4. Talking part merupakan partisipasi orang lain dalam percakapan sebagai upaya untuk membangun ataupun mengembangkan dan mempertahankan sebuah brand.

5. Tracking adalah pengawasan yang dilakukan oleh pihak perusahaan untuk mengantisipasi WOM negatif.

\section{Segmentasi Pasar}

Muhammad Dkk

(2011) mengungkapkan bahwa tidak semua konsumen sama, kalimat tersebut dimaknai setiap konsumen memiliki perilaku yang cenderung berbeda dalam memilih atau memutuskan untuk mengkonsumsi sebuah produk. Sehingga untuk memudahkan pemasar mengidentifkasi perilaku konsumen tersebut pemasar harus menerapkan strategi segmentasi, strategi tersebut dimaksudkan untuk memudahkan pemasar menganalisis kondisi pasar dalam ruang lingkup yang kecil, ataupun menjadi homogen.

Kasali dalam Setiadi (2010) mengungkapkan bahwa segmentasi merupakan proses mengotak-ngotakkan 
pasar yang heterogen ke dalam potensial konsumen yang memiliki kebersamaan kebutuhan dan atau kesamaan karakter yang memiliki respon yang sama dalam membelanjakan uangnya. Berdasarkan definisi yang diungkapkan oleh Kasali tersebut dapat ditarik satu kesimpulan bahwa untuk menyukseskan pemasaran starategi segmentasi sangat diperlukan, hal ini disebabkan kondisi pasar yang heterogen akan menyulitkan pemasar menentukan sasaran sehingga melalui segmentasi pemasar lebih fokus pada satu jenis konsumen dan meninggalkan konsumen lainnya.

Selain segmentasi, agar semakin memudahkan pemasar dalam menentukan target konsumen yang tepat langkah selanjutnya adalah merancang target market sebuah perusahaan. Target market dan segmentasi pasar merupakan dua hal yang tidak dapat dipisahkan, karena pemasar dengan mudah menentukan target market jika merujuk pada segmentasi pasar terlebih dahulu. Untuk memahami target market pemasar terlebih dahulu meneliti apa yang menjadi kebutuhan ataupun keinginan konsumen sehingga dapat menciptakan permintaan.

\section{Konsep Brand Positiong}

Tidak berbeda dengan bisnis lainnya, brand bagi sebuah bisnis kuliner juga sangat penting, maka untuk meningkatkan penjualan penciptaan brand dirasa sangat penting, perbedaan sebuah brand dengan pesaingnya akan sangat memudahkan pemasar untuk mendemonstrasikan keunggulan serta perbedaan dengan competitor. Kennedy dan Soemanagara (2006:109) mengungkapkan bahwa brand dapat disebut juga "pelabelan", sedangkan Straub dan Attner dalam Kennedy dan Soemanagara mengungkapkan bahwa brand is name, symbol, design, or combination og them that identifies the good or services of a company. Untuk melakukan penetrasi pasar dan memperkuat produk serta layanan adalah dengan melakukan branding, branding dimaknai sebagai usaha untuk memperkuat posisi produk di benak konsumen dengan cara menambah ekuitas dari nama sekumpulan produk.

Sedangkan positioning dimaknai sebagai strategi komunikasi yang berhubungan dengan bagaimana khalayak menempatkan suatu produk, merek, atau perusahaan dalam otaknya di dalam alam khayalanya sehingga khalayak memiliki penilaian tertentu menurut Morissan (2010:7). Senada dengan Morissan, Bhat dan Reddy (1998) dalam Sehrawala (2015) mengungkapkan, pada dasarnya positioning bukanlah apa yang dilakukan untuk sebuah 
produk melainkan bagaimana memposisikan sebuah produk dibenak masyarakat melalui proses komunikasi. Sehingga dari pemosisian tersebut menimbulkan persepsi yang dapat memotivasi konsumen untuk melakukan pembelian sebuah produk yang secara tidak langsung bertujuan untuk mengidentifikasi, dan mengambil kepemilikan, dasar pemikiran beli yang kuat yang memberi keuntungan serta membuat preposisi merek nyata atau dirasakan menurut Kapferer (2012).

Kapferer dalam Carlsson dan Linando (2012) mengemukakan dua tahap dalam positioning, tahap pertama yaitu memutuskan kategori merek dan tahap kedua yaitu menemukan perbedaan merek yang signifikan dibandingkan dengan produk dan merek di pasaran. Maka dapat disimpulkan bahwa memosisikan sebuah brand di benak konsumen merupakan salah satu cara bagi perusahaan untuk mendapatkan keuntungan finansial karena acuan bagi konsumen untuk melakukan pembelian terhadap satu produk sangat dipengaruhi oleh sebuah brand.

Tidak heran jika banyak perusahaan menempatkan brand dalam agenda prioritas mereka. Kapferer dalam Carlsson dan Linando mengungkapkan bahwa brand positioning menentukan perkembangan sebuah bisnis dalam pasar, melalui positioning menyiratkan sebuah ciri khas dari merek sehingga membuat merek tersebut berbeda dan menarik dengan merek lainnya. Aaker dalam Saagar dkk (2011) mengungkapkan bahwa brand positioning sebagai bagian dari proposisi identitas dan nilai, yang secara aktif berkomunikasi dengan target pasar. Ungkapan tersebut memperkuat bahwasanya dalam situasi bisnis kuliner yang semakin kompetitif mau tidak mau mendorong pemasar untuk menciptakan ciri khas agar brand tersebut mampu mempengaruhi keputusan pembelian konsumen.

Agar sebuah brand dapat terdeskripsikan dengan jelas, terkait maksimalisasi keunggulan-keunggulanya dalam pemasaran pada positioning sebuah brand. Kapferer (2008) merumuskan empat konsep yang harus diperhatikan oleh masing-masing pemasar agar dapat menciptakan ketepatan posisioning sebuah brand, yaitu a brand for what benefit mengacu pada janji merek dan manfaat konsumen, a brand for whom yakni mengacu pada aspek sasaran, reason mengacu pada unsur-unsur, faktual atau subjektif, yang mendukung manfaat sebuah merek serta a brand against whom menekankan pada pesaing utama. Pada 
penelitian ini lebih memfokuskan pada $a$ brand for what benefit mengacu pada janji merek dan manfaat konsumen, artinya melalui positioning sebuah brand, mampu menciptakan nilai serta menjawab ekspektasi konsumen terhadap sebuah brand melalui komunikasi dari mulut ke mulut.

\subsection{Kerangka Pemikiran}

Tax dalam Shi dkk (2012) mengungkapkan bahwa pada dasarnya word of mouth terdiri dari kategori negatif dan positif. Kategori tersebut tidak dapat dikendalikan oleh pemasar sehingga tugas pemasar tidak terletak pada upaya untuk mengendalikan persepsi baik dan buruknya sebuah brand melainkan bagaimana pemasar menciptakan posisi brand positif, maka untuk menciptakan word of mouth positif, pemasar tentunya memperhatikan lima aspek yang diungkapkan oleh Sernizer, hal tersebut guna untuk memperkuat posisi sebuah brand di benak konsumen. Merujuk pada ungkapan Kapferer bahwa dalam penelitian ini posisi brand yang dimaksudkan oleh peneliti lebih berfokus pada manfaat kepada konsumen artinya melalui word of mouth dapat menjawab ekspektasi konsumen terhadap sebuah konsep positioning brand dari angkringan The House of Raminten. Berdasarkan pemaparan di atas, maka kerangka pemikiran dalam penelitian ini digambarkan sebagai berikut: 
Sumber: Kotler \& Keller: 2012, Yu \& Tang dalam Virvialite: 2015 dan modifikasi peneliti
Komunikasi Pemasaran

The House of Raminten

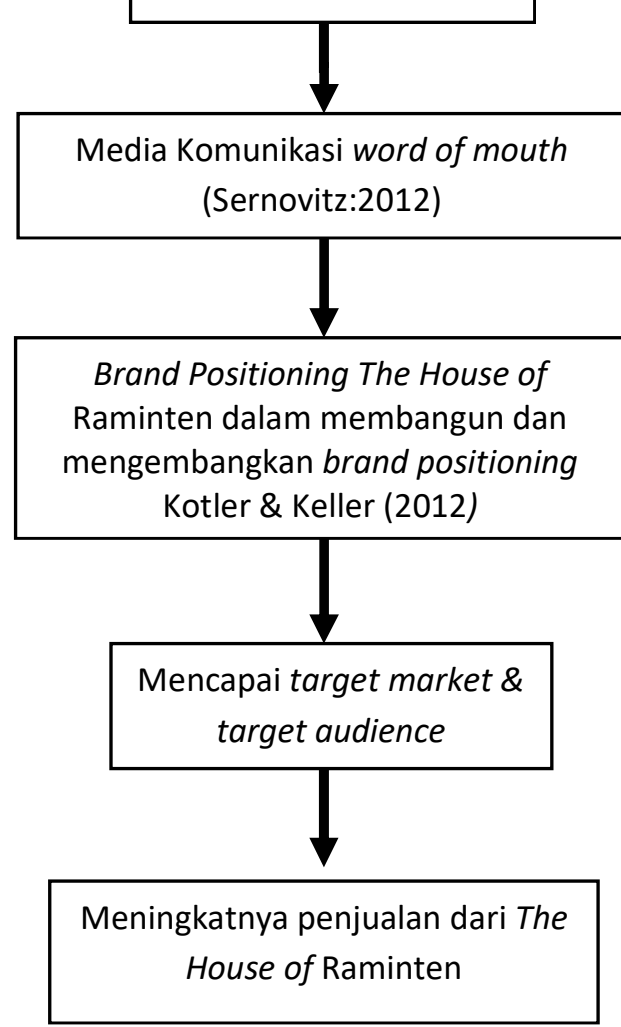

Gambar 1 Kerangka Pemikiran

\section{METODOLOGI PENELITIAN}

\section{Metodologi Penelitian}

\section{Metode Penelitian}

Dalam Ahmadi (2014) menurut Denzin dan Lincoln (1998:8) kata kualitatif menyatakan penekanan pada proses dan makna yang tidak diuji atau diukur dengan setepat-tepatnya dalam istilah-istilah kuantitas, jumlah, intensitas atau frekuensi. Para peneliti kualitatif menekankan sifat realitas yang dikonstruk secara sosial, hubungan yang intim antara peneliti dan apa yang distudi, kendala-kendala situasional yang membentuk inkuiri.

\section{Teknik Pengumpulan Data}

Teknik pengumpulan data pada peneltian ini menggunakan tiga teknik yaitu wawancara mendalam, dokumentasi, dan validitas data. Tiga penggunaan teknik tersebut dapat saling melengkapi informasi atau kebutuhan data peneliti dalam proses analisis word of mouth untuk memperkuat brand positioning di Angkringan The House of Raminten, adapun teknik pengumpulan data dapat dibedakan melalui 
data primer dan sekunder yang dijelaskan sebagai berikut:

Dalam penelitian ini berdasarkan cara perolehan dan sumber data maka dibedakan menjadi:

\section{Data primer}

Menurut Umar (2011:42) data primer merupakan data yang didapat dari sumber pertama baik dari individu atau perseorangan seperti hasil wawancara atau hasil pengisian kuesioner yang biasa dilakukan oleh peneliti. Dalam hal ini peneliti memperoleh data atau informasi langsung dengan menggunakan instrumeninstrumen yang ditetapkan. Data tersebut adalah sebagai berikut:

a. Wawancara

Pengumpulan data primer pada penelitian ini dilakukan dengan wawancara mendalam. Wawancara mendalam adalah suatu cara mengumpulkan data atau informasi dengan cara langsung bertatap muka dengan informan agar mendapatkan data lengkap dan mendalam. Wawancara ini dilakukan dengan frekuensi tinggi (berulang-ulang) secara intensif menurut Kriyantono (2008:100). Pada penelitian ini, peneliti mewawancarai Bapak Hamzah selaku pemilik The House of Raminten, General Manager dari The House of
Raminten yaitu Ibu Liza, dan tiga pengunjung dari The House of Raminten. Pemilihan tiga pengunjung menurut peneliti merupakan salah satu upaya untuk melakukan pengecekan terhadap keabasahan data hasil wawancara. Selain itu, penentuan tiga pengunjung, menurut peneliti, telah merepresentasikan kevalidan hasil wawancara dikarenakan penelitian ini menggunakan metode kualitatif di mana metode yang mengedepankan tentang kualitas bukan kuantitas semata.

\section{b. Observasi}

Observasi diartikan sebagai kegiatan mengamati secara langsung tanpa adanya mediator suatu objek untuk melihat dengan dekat kegiatan yang dilakukan objek tersebut. Teknik ini menuntut adanya pengamatan dari peneliti baik secara langsung maupun tidak langsung terhadap objek penelitiannya menurut Kriyantono (2008:108).

\section{Data sekunder}

Data sekunder merupakan data yang didapatkan dari buku serta materi tertulis atau dari hasil penelitian sebelumnya yang relevan dengan tujuan penelitian. Data sekunder ini diperoleh melalui studi kepustakaan baik berupa dokumen atau 
arsip-arsip tertulis lainnya maupun dokumentasi.

\section{Analisis Data}

Analisis data, menurut Patton, adalah proses mengatur urutan data, mengorganisasikannya ke dalam suatu pola, kategori, dan satuan uraian dasar menurut Moleong (2004:103). Proses analisis data dimulai dengan menelaah seluruh data yang tersedia dari berbagai sumber yaitu dari wawancara, pengamatan yang sudah dituliskan dalam catatan lapangan, serta dokumen-dokumen. Dalam penelitian kualitatif ini, data diperoleh dari berbagai sumber dengan menggunakan teknik pengumpulan data yang bermacam-macam (triangulasi). Miles dan Huberman (1984) mengemukakan bahwa aktivitas dalam analisis data ada tiga tahap yakni data reduction, data display, dan conclusion menurut Sugiyono (2008:246)

\section{Reduksi data (data reduction)}

Data yang diperoleh dari lapangan jumlahnya cukup banyak, karena itu perlu dicatat secara teliti dan rinci. Mereduksi data berarti merangkum, memilih hal-hal yang pokok, memfokuskan pada hal-hal penting. Dengan demikian, data yang telah direduksi akan memberikan gambaran yang lebih jelas dan mempermudah peneliti untuk melakukan pengumpulan data selanjutnya, dan mencarinya jika diperlukan menurut Sugiyono (2008:247).

\section{Penyajian data (data display)}

Setelah data direduksi, maka langkah selanjutnya adalah menyajikan data. Dalam penelitian kualitatif, penyajian data bisa dilakukan dalam bentuk uraian singkat, bagan, hubungan antarkategori, dan sejenisnya. Miles dan Huberman (1984) menyatakan bahwa bentuk yang paling sering digunakan untuk menyajikan data kualitatif adalah teks yang bersifat narasi menurut Sugiyono (2008:249).

\section{Penarikan simpulan (conclusion)}

Langkah ketiga dalam analisis data kualitatif menurut Miles dan Huberman (1984) adalah penarikan kesimpulan dalam Sugiyono (2008:252). Kesimpulan dalam penelitian kualitatif adalah merupakan temuan baru yang sebelumnya belum pernah ada. Temuan dapat berupa deskripsi atau gambaran suatu objek yang masih remang-remang atau gelap sehingga setelah diteliti menjadi jelas, dapat 
juga berupa hubungan kausal atau interaktif, dan hipotesis atau teori.

Setelah melakukan analisis data, data diinterpretasikan dengan melakukan korelasi terhadap teori yang ada. Selama proses interpretasi data, tetap dilakukan studi kepustakaan terutama untuk melakukan konfirmasi terhadap teori.

\section{HASIL PENELITIAN}

\section{The House of Raminten sebagai} Angkringan Tradisional Modern

Sejak awal berdirinya pada 2008, Raminten telah mengalami tiga perubahan konsep. Perubahan konsep didasarkan pada perilaku pasar saat itu. Di tahun pertama berdiri, Raminten memosisikan diri sebagai angkringan sederhana dengan target audience yakni pelanggan angkringan pada umumnya. Namun pada 2009 target audience dari The House of Raminten lebih difokusukan pada rentang usia 17 hingga 35 tahun dengan memperkenalkan jamu sebagai minuman sehat yang tidak hanya dikonsumsi oleh wanita ataupun orang yang sedang mengalami gangguan kesehatan. Bapak Hamzah sebagai pemilik The House of Raminten memposisikan jamu sebagai minuman berkhasiat namun tetap memiliki rasa enak serta bisa dinikmati saat santai bersama keluarga. Usaha jamu tradisional tersebut tidak berlangsung lama, melihat pariwisata Kota Yogyakarta semakin mengalami peningkatan, pada 2010 pihak The House of Raminten memperluas segmentasi pasar mereka menjadi tidak terbatas hanya pada remaja saja melainkan terhadap semua audience dengan konsep "tradisionl modern".

Konsep tradisional modern diimplementasikan melalui pembenahan tata ruang atau atmosfer ruang didasarkan pada tiga kata kunci yaitu unik, antik, dan elegan. Tiga kata tersebut telah terepresentasikan melalui atmosfer The House of Raminten, misalnya pengunjung disuguhkan dengan nuansa budaya Jawa mulai dari desain eksterior hingga interior. Pada bagian depan The House of Raminten terdapat gambar seorang wanita menggunakan pakaian tradisional Jawa dilengkapi dengan sanggul, sedangkan pada bagian interior The House of Raminten didesain secara tradisional misalnya bangunan yang didesain dengan arsitektur tradisional yang unik dihiasi kereta kencana, dokar, patung, serta alunan musik gamelan. Tidak hanya ruangan, nuansa Jawa juga diperlihatkan dari penampilan pelayan di The House of Raminten dengan menggunakan kemben, rompi, serta jarik yang bercorak batik Jawa, semakin menambah keunikan The House of Raminten, komunikasi antarpelayan 
menggunakan handy talkie. Keunikan juga ditonjolkan pada menu serta peyajiannya yang unik dan nyentrik, misalnya menu khas mereka "sego kucing" yaitu porsi nasi sedikit mirip dengan makanan kucing. Sedangkan konsep modern yakni menciptakan angkringan dalam konsep yang lebih modern serta elegan.

Dalam perjalananya membangun The House of Raminten, Bapak Hamzah tidak pernah menggunakan media komersial untuk memperkenalkan The House of Raminten kepada masyarakat luas. Menurutnya, promosi The House of Raminten terjadi begitu saja berdasarkan pada pengalaman konsumen yang pernah datang atau mengunjungi The House of Raminten. Artinya, tiap konsumen berpotensi sebagai promotor untuk menarik minat pengunjung ke Raminten. Istilah gethok tular atau komunikasi dari mulut ke mulut (word of mouth) berperan penting terhadap kesuksesan The House of Raminten menjadi salah satu ikon wonderful Indonesia.

Pengunjung memberikan rekomendasi bagi kerabat, rekan kerja, teman mereka terkait keberadaan The House of Raminten di Yogyakarta, misalnya melalui pesan tentang konsep The House of Raminten dengan nuansa tradisional modern. Pesan tersebut diterima oleh komunikan sehingga menjadi input untuk menciptakan ekspektasi mereka terhadap nuansa tradisional modern pada The House of Raminten. Hal tersebut telah dibuktikan peneliti melalui wawancara dengan pengunjung The House of Raminten. Sebagian besar pengunjung yang datang adalah wisatawan lokal maupun internasional yang memang telah mengagendakan kunjungan ke The House of Raminten. Informasi tentang The House of Raminten didapatkan melalui rekomendasi teman ataupun pencarian di internet.

Menurut mereka, informasi tersebut telah membentuk satu persepsi terkait The House of Raminten, yakni konsep tradisional modern. Artinya, posisi brand The House ofRaminten telah tercipta $\mathrm{di}$ benak konsumen sebelum mereka datang atau berkunjung ke tempat tersebut. Mengingat The House of Raminten, sama halnya mengingat budaya Jawa yang dipadukan dengan nuansa modern. Konsep tersebut merupakan stimulus utama bagi pengunjung karena perbedaan yang ditampilkan oleh The House of Raminten melalui media komunikasi dari mulut ke mulut.

Word of Mouth untuk Memperkuat Brand Positioning The House of Raminten 
Word of mouth merupakan salah satu jenis komunikasi pemasaran yang secara informal digunakan oleh para pemasar. Pada sistem ini, pemasar bukan merupakan sentral informasi terhadap produknya. Word of mouth melibatkan konsumen atau pengunjung menjadi promotor untuk menarik minat pengunjung lainnya, melalui review atau rekomendasi kepada sahabat, rekan, ataupun masyarakat luas secara tatap muka hingga virtual. Keadaan ini secara tidak langsung membuat pemasar tidak dapat mengontrol penyebaran pesan sehingga berpotensi menimbulkan pesan negatif ataupun positif.

Mengingat penyebaran pesan melalui word of mouth tidak dapat dikontrol oleh pemasar, maka pemasar seharusnya mampu memanfaatkan word of mouth sebagai fenomena yang menguntungkan bagi mereka. Sehingga, perlu dipersiapkan sebuah konsep unik, kualitas produk, hingga pelayanan prima sebagai upaya untuk menciptakan word of mouth positif terhadap sebuah brand. Brand bagi sebuah produk sangatlah penting, brand dapat merepresentasikan kualitas sebuah produk. Bukan hanya itu, melalui brand, konsumen dapat mengetahui perbedaan sebuah produk dengan kompetitornya. Brand atau pelabelan harus mendapatkan posisi di benak konsumen. Artinya, ketika sebuah produk disebutkan, dengan cepat konsumen dapat mengenali atau mengidentifikasi ciri khas dari produk tersebut. Memposisikan brand di benak konsumen berarti melekatkan sebuah brand melalui penciptaan makna, konsep brand yang ditawarkan merupakan sebuah janji dan manfaat kepada konsumen sehingga menciptakan ekspektasi tinggi bagi mereka melalui penciptaan keunggulan brand sebagai upaya merangkum posisi dan esensi dari brand tersebut.

Memperkuat sebuah posisi brand melalui word of mouth khususnya pada The House of Raminten telah terimplementasikan sejak lama dengan menyebut konsep ini sebagai getok tular. Word of mouth memiliki peran kuat terhadap posisi brand The House of Raminten di Yogyakarta. Ungkapan tersebut didasarkan pada analisis peneliti terkait promosi yang telah dilakukan oleh pihak Raminten yang kemudian dipertegas melalui wawancara dengan pihak manajemen The House of Raminten sebagai berikut:

Pihak manajemen Raminten tidak pernah melakukan pemasangan iklan di media televisi, mengingat segmentasi pasar konsumen dari Angkringan ini, selain itu iklan 
melalui media massa dinilai kurang ampuh untuk mempengaruhi Perilaku

Konsumen.

Minat pengunjung untuk datang ke The House of Raminten dilatarbelakangi oleh kisah atau cerita teman mereka terkait konsep tradisional modern angkringan The House of Raminten. Artinya, persepsi konsumen telah terbentuk dengan adanya aktivitas word of mouth yang disampaikan oleh seorang komunikator atau talkers. Ungkapan Sernoviz (2012) terkait efektivitas word of mouth dapat direpresentasikan melalui penelitian ini. Talkers merupakan pengunjung yang telah menyampaikan nilai atau konsep yang ditawarkan oleh The House of Raminten melalui saluran word of mouth. Rekomendasi darinya merupakan input bagi calon konsumen sehingga menciptakan ekspektasi terhadap The House of Raminten. Ekspektasi tersebut terjawab jika konsumen secara langsung mengunjungi tempat tersebut. Setelah mengunjungi The House of Raminten, seorang pengunjung berpotensi menjadi talkers bagi calon konsumen baru. Fenomena ini ibarat mata rantai yang tidak pernah putus. Artinya, akan ada pengunjung yang selalu berpotensi menjadi talkers.
Untuk mengantisipasi hal tersebut, agar posisi brand selalu melekat di benak pengunjung, perlu melakukan evaluasi ataupun pengawasan terkait persepsi konsumen terhadap konsep angkringan mereka. Terlebih lagi pada bisnis kuliner yang semakin kompetitif, konsumen semakin dimanjakan dengan menjamurnya bisnis kuliner yang secara tidak langsung memberikan kemudahan untuk mencoba produk baru. Pada kasus The House of Raminten, sesuai ungkapan Kotler dan Keller (2012), melalui word of mouth, konsep tradisional modern yang mereka usung direpresentasikan melalui atmosfer yang kemudian disampaikan melalui dialog para pengunjung terhadap masyarakat. Komunikasi dua arah yang terjadi melalui word of mouth dapat memberikan input bagi komunikan untuk mengunjungi angkringan The House of Raminten yang didasarkan pada penuturan komunikator. Kesuksesan word of mouth pada komunikasi pemasaran yang dilakukan oleh pihak The House of Raminten sebenarnya tidak lepas dari kematangan strategi pihak The House of Raminten.

Peran besar word of mouth dalam menciptakan posisi sebuah brand dalam benak konsumen pada The House of Raminten tidak luput dari kontribusi karakteristik yang dimilikinya, seperti 
ungkapan Yu \& Tang dalam Virvilaite dkk (2015) mengungkapkan karakteristik dari word of mouth yaitu menarik dan kegunaan, serta dapat mempengaruhi konsumen. Pernyataan pesan menarik dan kegunaan tentunya telah dimiliki oleh The House of Raminten sebagai syarat meningkatkan peran word of mouth. Menarik dimaknai dengan pesan keragaman, peran pesan sangat kuat untuk menentukan persepsi konsumen terhadap sebuah produk. Sebelumnya dapat dilihat pada hasil penelitian yakni melalui pesan nonverbal The House of Raminten yang telah merepresentasikan posisi di benak konsumen misalnya saja melalui atmosfer, serta pelayanan yang semuanya telah mewakilkan konsep tradisional namun tidak meninggalkan unsur modern. Sedangkan kegunaan dapat dimaknai dari frekuensi penggunaan, jumlah orang, dengan siapa pengirim informasi berkomunikasi dan jumlah informasinya.

Konsep WOM merupakan konsep penyampaian pesan dari mulut ke mulut yang dilakukan oleh pengunjung atau konsumen kepada teman, saudara hingga masyarakat luas baik melalui medium tatap muka ataupun ungkapan melalui media online. Manajemen the House of Raminten dengan tegas mengungkapkan hal tersebut seperti :
Banner merupakan medium cadangan dalam promosi Raminten, kami menaruhnya di lokasi-lokasi strategis misalnya bandara dengan tujuan untuk menarik konsumen baru, melalui tampilan yang berbeda tentunya wisatawan menjadi penasaran. Namun yang menjadi medium utama adalah memanfaatkan pengunjung atau konsumen sebagai medium penyampaian pesan terkait keberadaan angkringan ini.

Ungkapan manajemen Raminten di atas, peneliti menarik satu kesimpulan terdapat dua medium yang digunakan oleh pihak manajemen Raminten, medium utama adalah pemanfaatan pengunjung atau konsumen sebagai medium penyampaian pesan dan medium cadangan 'banner' untuk memperkenalkan kepada pengunjung baru. Ungkapan di atas sebenarnya secara implisit menjelaskan bahwa WOM merupakan medium ampuh untuk memperkenalkan Raminten pada masyarakat khususnya wisatawan lokal mapun mancanegara. 
Karaktersitik word of mouth mampu memberikan kontribusi bukan hanya pada minat beli saja, melainkan memperkuat posisi brand di benak konsumen, sepanjang para pemasar mengerti atau memenuhi karakteristik yang telah dipaparkan sebelumnya. Lebih dalam membahas tentang karakteristik pesan menarik, pemasar dalam hal ini pihak manajemen Raminten merepresentasikannya melalui pelayanan hingga atmosfer ruangan akan ditransmisikan oleh komunikator sebagai rekomendasi dengan pesan yang jelas bahwa konsep di The House of Raminten menggambarkan konsep tradisional modern. Karakteristik yang tidak kalah penting dalam penyampaian pesan dari mulut ke mulut adalah frekuensi pengguna, dalam hal ini pengguna dimaknai sebagai seorang konsumen yang menjadi komunikator (talkers) dalam pemberian rekomendasi (topic). Sehingga semakin tinggi frekuensi berkunjung, semakin besar kemungkinan konsumen dalam memberikan rekomendasi.

Perlu diketahui posisi sebuah brand di benak konsumen muncul melalui ekspektasi dari rekomendasi pengunjung, posisi sebuah brand semakin diperkuat ketika semakin banyak orang membicarakan sebuah brand. Berdasarkan hasil penelitian bagaimana seorang komunikator merekomendasikan The House of Raminten sebagai icon kuliner Kota Yogyakarta yang merepresentasikan budaya Jawa, secara tidak langsung memunculkan ekspektasi konsumen terhadap posisi usaha kuliner ini.

Selain karaktersitik yang dimiliki oleh word of mouth dalam memperkuat brand positioning The House of Raminten, pemasar yakni General Manager atau pemilik The House of Raminten juga harus paham bagaimana cara memperkuat posisi sebuah brand melalui word of mouth. Perlu menjadi perhatian pemasar memaknai positioning sebuah brand pemasar tidak terfokus pada sebuah produk, melainkan fokus melalui cara bagaimana memposisikan sebuah produk di benak konsumen dengan tujuan untuk meningkatkan minat bagi konsumen agar berkunjung ke The House of Raminten. Selain itu, perlu menjadi pehatian khusus bahwa penciptaan posisi sebuah produk bukan merupakan sesuatu yang instan namun memiliki tahapan-tahapan dalam proses mendapatkan posisi tersebut seperti ungkapan Kapferer dalam Carlsson dan Linando (2012).

Tahapan-tahapan tersebut menurut peneliti telah dilewati oleh pihak The House of Raminten, sebelum menerapkan word of mouth sebagai medium promosi, pihak The 
House of Raminten telah melakukan tahapan positioning. Tahapan pertama yang dilakukan oleh pihak The House of Raminten yakni memutuskan kategori merek seperti apa yang akan mereka usung yakni konsep tradisional modern. Setelah menentukan merek pihak The House of Raminten tentu saja mencari perbedaan terhadap konsep yang mereka ciptakan. Peran word of mouth terjadi setelah pemasar menerapkan atau melalui tahapan tersebut, isi pesan komunikator dapat merepresentasikan konsep yang telah ditentukan oleh pemasar tersebut mulai dari perbedaan hingga menciptakan ciri khas tersendiri bagi pemasar. Telah dijelaskan sebelumnya bagaimana word of mouth dalam memperkuat brand positioning. Dari hasil wawancara dengan pihak manajemen dan pemilik The House of Raminten Bapak Hamzah, dapat ditarik satu kesimpulan bahwa peran word of mouth sangat tinggi dalam memperkuat brand positioning. Tidak hanya sampai pada upaya memperkuat posisi brand terhadap konsumen saja.

\section{SIMPULAN}

Dalam dunia industri kuliner Tanah Air, konsep word of mouth bukan merupakan hal baru, ketatnya persaingan memberikan tekanan bagi pemasar untuk melakukan strategi kreatif dalam perencanaan hingga penggunaan media dengan tujuan untuk menciptakan kesadaran masayarakat terhadap produkproduk yang mereka ciptakan. Konsep word of mouth banyak digunakan pada industri kuliner, dapat dilihat di berbagai daerah yang banyak memanfaatkan pengalaman-pengalaman konsumen sebagai bahan rekomendasi.

Hal tersebut sebenarnya tidak secara terang-terangan diucapkan oleh pemilik bisnis, namun melalui pelayanan terbaik hingga tata ruang, memberikan stimulus bagi konsumen untuk dapat menceritakan ke pengunjung lain. Berdasarkan hasil wawancara dan observasi peneliti, dapat ditarik satu kesimpulan bahwa getok tular istilah yang digunakan oleh The House of Raminten untuk Word of Mouth ini mempunyai peran yang sangat tinggi dalam memperkuat brand positioning. Tidak hanya sampai pada upaya memperkuat posisi brand terhadap konsumen saja, dalam penelitian ini juga ingin mendeskripsikan media komunikasi word of mouth dapat mencapai sasaran yang tepat dengan target market dan target audience yang jelas sesuai segmentasi pasar The House of Raminten. 


\section{Daftar Pustaka}

\section{Buku :}

Ahmadi, Rulam. 2014. Metodologi Penelitian Kualitatif. Yogyakarta : ArRuzzmedia.

Kapferer, JN. 2008. The New Strategic Brand Management: Cretaing and Sustaining Brand Equity Long Term, $4^{\text {th }}$ edition. London \& Philadelpia: Kogan Page.

Kennedy, Jhon E dan Soemanagara, R Dermawan. 2006. Marketing Communication Taktik \& Strategy. Jakarta: Penerbit BIP.

Kotler, Philip \& Kevin Lane Keller. 2012. Marketing Management 13. New Jersey: Person Prentice Hall, Inc.

Kriyantono, Rachmat. 2008.Teknik Praktis Riset Komunikasi. Jakarta: Penerbit Kencana.

Moleong, Lexy J. 2004. Metodologi Penelitian Kualitatif. Bandung: Remaja Rosdakarya.

Morissan. 2010. Periklanan: Komunikasi Pemasaran Terpadu. Jakarta: Penerbit Kencana.

Sangadji dan Sopiah. 2013. Perilaku Konsumen - Pendekatan Praktis, Yogyakarta: Penerbit Andi.

Sernoviz, Andy. 2012. Word of Mouth Marketing How Smart Companies Get People Talking. Austin: Greenleaf Book Group Press.

Setiadi, Nugroho J. 2010. Perilaku Konsumen (Konsep dan Implikasi untuk Strategi dan Penelitian Pemasaran).

Jakarta: Prenada Media.

Sugiyono. 2008. Metode Penelitian Kuantitatif, Kualitatif dan $R \& D$. Jakarta: Alfabeta.

Umar, Husein. 2011. Metode Penelitian untuk Skripsi dan Tesis Bisnis. Jakarta: PT Raja Grafindo Persada.

\section{Website:}

(http://jogja.tribunnews.com/2016/12/14/le ngth-of-stay-rendah-targetkan-spendingtinggi-dari-wisatawan?page $=1$ ) diakses pada tanggal 11 Januari 2017.

(http://jogja.tribunnews.com/2016/12/14/le ngth-of-stay-rendah-targetkan-spendingtinggi-dari-wisatawan?page $=2$ ) diakses pada tanggal 11 Januari 2017.

(http://www.kompasiana.com/primaratih/r aminten-cafe-unik-khas-

yogyakarta 55299e35f17e61920ed623b7) diakses pada tanggal 28 Mei 2017.

(https://yudasmoro.net/2013/03/29/houseof-raminten-sukses-dengan-ide-nyeleneh/) diakses pada tanggal 28 Mei 2017.

(http://www.nielsen.com/id/en/pressroom/2015/REKOMENDASI-WORD-OFMOUTH-MASIH-MENJADI-IKLANPALING-DIPERCAYA-OLEHKONSUMEN-ASIA-TENGGARA.html) diakses pada tanggal 28 Mei 2017.

\section{Artikel Jurnal Ilmiah :}

Carlsson, Carolina \& Linader, Kristina. 2012 Positioning of a brand Point Of Parity: A

Study of a Possible Aproach for Taking Position a Poin Of Parity in a Mature Business to Business 
Market. Master of Science Thesis. KTH Industrial Engineering and Management. Stocklhom Sweden. Diakses pada tanggal 12 Januari 2017.

http://scholar.google.co.id/scholar_ url?url=http://bluecubeco.com/dow nload/book/03.pdf\&hl=id\&sa=X\&s cisig=AAGBfm2d_QwDxQxoQihl kc7GUzE1hdJ5Q\&nossl=1\&oi=sc holarr\&ved=0ahUKEwisiIHg9LTR AhXJPI8KHTHTDH0QgAMIGCg $\underline{\text { AMAA }}$

Casielles, R.V. Alvarez. A.S \& Del Rio Lanza, A.B. 2013. The Word Of Mouth

Dynamic How Positve (and Negative) WOM Drives Purchase Probability: An Analysis of Interpersonal Factor. Journal of Advertising Research. Vol. $53 \mathrm{Hal}$ 43-60. Diakses pada tanggal 10 Januari 2017. http://www.emeraldinsight.com.ezp roxy.ugm.ac.id/doi/pdfplus/10.1108 /APJML-07-2013-0089

Gunawan, Arie Indra, 2013, Pengaruh Brand Positioning Terhadap Loyalitas Pelanggan Surat Kabar Pikiran Rakyat (Survey Terhadap Pembaca Surat Kabar Pikiran Rakyat di Kota Bandung ).

Vol.1, no.2, September 2013, diakses pada tanggal 11 Januari 2017.

http://fkip-

unswagati.ac.id/ejournal/index.php/eduno mic/article/ download 127/26.

Muhammad, Rusnah. Melawar, T.C \& Alwi, S.F.S. 2011. Segmentation and Brand For Islamic Services. Europan Journal of Marketing, Vol. 46. No. $7 / 8$. Diakses pada tanggal 12 Januari 2017. http://www.emeraldinsight.com.ezp roxy.ugm.ac.id/doi/pdfplus/10.1108 /03090561211230061

Saagar, Mahim. Khandelwal, Rishabh. Miftal, Amit \& Singh, Deepali. 2011. Ethical

Positioning Index (EPI): An Innovative Tool for Differential Brand Positioning. Corporate Communication an International Journal. Vol 16. Hal. 124-138. Diakses pada tanggal 10 Januari 2017.

http://www.emeraldinsight.com.ezp roxy.ugm.ac.id/doi/pdfplus/10.1108 /13563281111141651.

Sehrawala, Sameer. 2015. Brand Positioning Strategies of Coffee Shop in Turkey: A Comparative Study of Starbucks and Costa Coffee. International Journal of Economics, Commerce and Management, United Kingdom. Vol. III, Issue 5, May 2015. Diakses pada tanggal 12 Januari 2017.

http://ijecm.co.uk/wp-

content/uploads/2015/05/3532.pdf

Shi, Wenhua. Tang, Lingshu. Zhang, Xiaohang, Gao, Yu \& Zhu Yameng. 2015. How

Does Word Of Mouth Affect Customer Satisfication?. Journal of Businees \& Marketing. Vol. 31, No. 3 Hal 393-403. Diakses pada tanggal 10 Januari 2017. http://www.emeraldinsight.com.ezp roxy.ugm.ac.id/doi/pdfplus/10.1108 /JBIM-07-2014-0139

Viglia, Giampolo. Minazzi \& Buhalis, Dimitrio. 2016. The Influence of eWord-of mouth on Hotel Occupancy Rate. International Journal of Contemporary Hospitality Management. Diakses 
pada 10 Januari 2017, www.emeraldinsight.com/0959-

6119.htm

Virvialite, Regina. Tumasonyte, Dovile \&Sliburyte, Laimona. 2015. The Influence

of Word of Mouth Communication on Brand Equity: Receiver Perspective Procedia- Social and
Behavioral Sciences 213. Hal.641646. Di akses pada tanggal 10 Januari 2017.

http://www.sciencedirect.com.ezpr oxy.ugm.ac.id/science/article/pii/S1 $\underline{877042815058206 / p d f ? \mathrm{md} 5=\mathrm{e} 286 \mathrm{~d}}$ 6b3ea7dbc62919f047c586f16c\&pi $\mathrm{d}=1-\mathrm{s} 2.0-\mathrm{S} 1877042815058206-$ main.pdf 